Orthopäde $2021 \cdot 50: 674-680$

https://doi.org/10.1007/s00132-021-04068-x

Accepted: 10 January 2021

Published online: 11 February 2021

(c) The Author(s) 2021

\author{
Ricarda Lechner' $\cdot$ Matteo Lazzeri' ${ }^{1}$ Wilhelm Oberaigner ${ }^{2,3}$ - Paul Nardelli' \\ Tobias Roth ${ }^{1}$ Paul Köglberger ${ }^{1,4,5}$ • Martin Krismer ${ }^{1}$. \\ Michael Christian Liebensteiner ${ }^{1}$ \\ 'Department of Orthopaedics and Traumatology, Medical University Innsbruck, Innsbruck, Austria \\ ${ }^{2}$ Institut für klinische Epidemiologie, Tirol Kliniken, Innsbruck, Austria \\ ${ }^{3}$ UMIT-Private University for Health Sciences, Medical Informatics and Technology, Hall, Austria \\ ${ }^{4}$ Department of Anesthesiology and Critical Care Medicine, Klinikum Wels-Grieskirchen, Wels, Austria \\ ${ }^{5}$ Division of Intensive Care and Emergency Medicine, Department of Internal Medicine, Medical University \\ Innsbruck, Innsbruck, Austria
}

\section{Does the type of surgical approach affect the clinical outcome of total knee arthroplasty?}

\section{Introduction}

Up to $30 \%$ of patients were reported to dissatisfied with the outcome of total knee arthroplasty (TKA) because of unexplained pain $[9,15]$. When discussing patient dissatisfaction following TKA a differentiation can be made between implant-related, patient-related and surgery-related factors $[8,12,22]$.

Regarding surgery-related factors previous researchers discussed the role of different surgical approaches on outcome after TKA $[11,13,18]$. So far, 12 studies have compared the medial midvastus approach (MMV) and the medial parapatellar approach (MPP) and provided several clinical outcome parameters after TKA $[1,2,4-6,10,14,17,19,20,23$, 25]. Those studies were in part incongruent in that six of those studies favoured the MMV approach [1, 2, 4, 19, 23, 25], while the other six studies reported no such advantages $[5,6,10,14,17,20]$. There seems to be a slight advantage of the MMV approach in terms of quadriceps strength, active straight leg raise and partially also patient-reported outcomes only in the very early postoperative period (weeks 1 and 2). With respect to sample size most of those publications provided 20 or 30 patients per group.
Due to the abovementioned conflicting evidence and the rather small sample sizes it was the aim of the study to investigate the issue of MMV vs. MPP approach in TKA once again but on the basis of much larger study populations. It was hypothesized that the two surgical approaches would lead to significantly different results with respect to patientreported knee score outcome (hypothesis 1), short-term postoperative ROM (hypothesis 2), long-term postoperative ROM (hypothesis 3 ) and prosthesis survival (hypothesis 4).

\section{Material and methods}

A retrospective comparative study design was applied. Data available from clinical routine were analyzed after approval by the IRB of the authors' affiliated institutions. Patients who previously underwent primary TKA as part of the clinical routine were analyzed. Data sets were obtained from the state arthroplasty registry and covered all primary TKA cases performed at Department of Orthopaedics and Traumatology, Medical University of Innsbruck, Innsbruck, Austria from 2008 to 2015. Cases were excluded in the case of a) surgical approaches other than MPP and MMV, b) implants other than Scorpio CR or Triathlon CR (Stryker,
Kalamazoo, MI, USA), c) incomplete preoperative WOMAC data and d) incomplete postoperative WOMAC data (1 year) (• Fig. 1).

Information on whether an MPP or an MMV approach had been applied was extracted from the arthroplasty registry database. While one group of surgeons routinely performed the MMV approach another group routinely used the MPP approach for primary TKA. The prosthesis was implanted according to the manufacturer's instructions using a measured

\begin{tabular}{|ll}
\hline \multicolumn{2}{|l}{ Abbreviations } \\
\hline IRB & Institutional review board \\
\hline KSS & Knee Society score \\
\hline LRR & Lateral retinacular release \\
\hline mFTA & Mechanical femorotibial angle \\
\hline MMV & Medial midvastus approach \\
\hline MPP & Medial parapatellar approach \\
\hline Q-strength & Quadriceps muscle strength \\
\hline ROM & Range of motion \\
\hline SLR & Straight leg raise \\
\hline TKA & Total knee arthroplasty \\
\hline VAS & Visual analogue scale \\
\hline WOMAC & $\begin{array}{l}\text { Western Ontario and McMaster } \\
\text { Universities osteoarthritis index }\end{array}$ \\
\hline
\end{tabular}




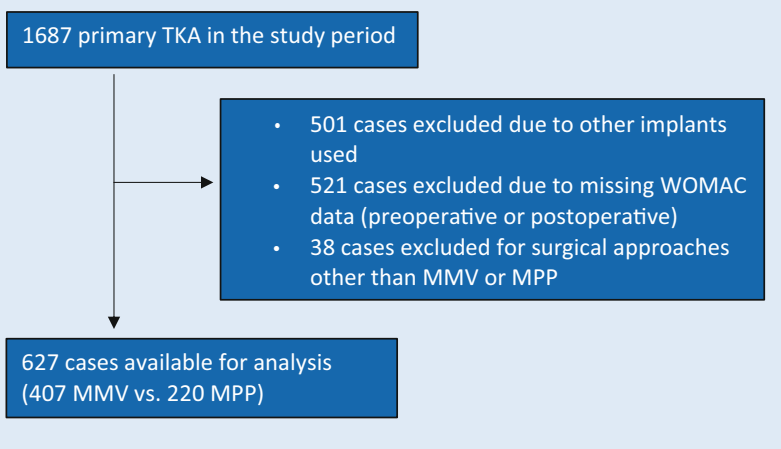

Fig. $1 \Delta$ Flow chart of excluded patients. TKA total knee arthroplasty, $M M V$ medial midvastus approach, MPP medial parapatellar approach, WOMAC Western Ontario and McMaster Universities osteoarthritis index

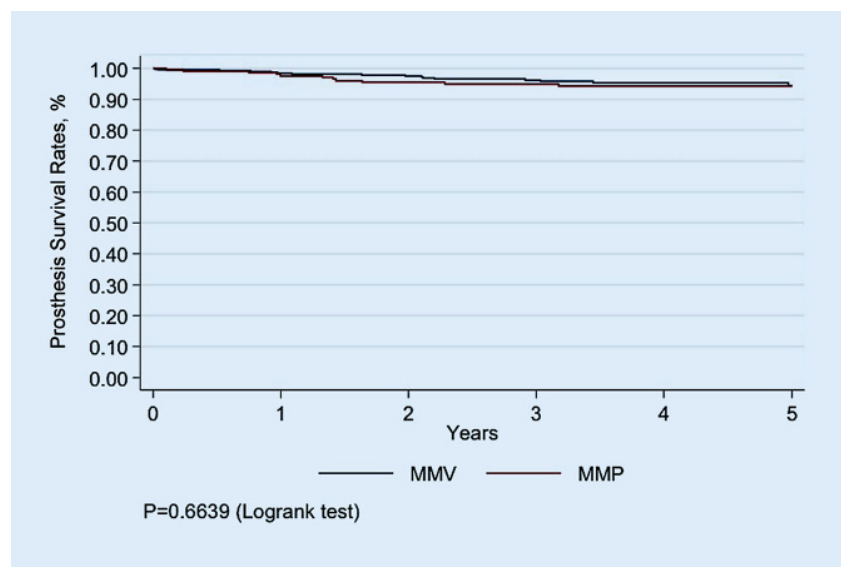

Fig. $2 \Delta$ Graph showing prosthesis survival for the medial midvastus approach (MMV) group and the medial parapatellar approach (MPP) group as provided by the state arthroplasty registry
Table 1 Mechanical femorotibial angle ( $\mathrm{mFTA}$ ) and WOMAC score and preoperative range of motion (ROM), short-term postoperative ROM (days 4 and 10), WOMAC score and long-term postoperative ROM ( 1 year) for both groups

\begin{tabular}{|c|c|c|c|c|c|}
\hline & \multicolumn{2}{|l|}{ MMV } & \multicolumn{2}{|l|}{ MPP } & \multirow[b]{2}{*}{$p$-value } \\
\hline & Mean & SD & Mean & SD & \\
\hline mFTA preop & 182.6 & 6.6 & 182.2 & 7.1 & 0.479 \\
\hline WOMAC pain preop & 48.7 & 21.0 & 49.7 & 20.8 & 0.3704 \\
\hline WOMAC stiffness preop & 54.4 & 25.9 & 52.3 & 25.4 & 0.3128 \\
\hline WOMAC function preop & 51.5 & 20.8 & 51.5 & 21.2 & 0.9060 \\
\hline WOMAC total preop & 51.6 & 20.0 & 51.2 & 19.7 & 0.9216 \\
\hline ROM preop $\left(^{\circ}\right)$ & 109.5 & 16.2 & 108.0 & 15.6 & 0.282 \\
\hline ROM day $4\left(^{\circ}\right)$ & 66.8 & 14.6 & 68.1 & 15.2 & 0.305 \\
\hline ROM day $10\left(^{\circ}\right)$ & 88.6 & 11.8 & 87.5 & 12.5 & 0.383 \\
\hline WOMAC pain 1 year & 15.7 & 18.9 & 17.2 & 20.1 & 0.6952 \\
\hline WOMAC stiffness 1 year & 23.1 & 21.8 & 25.0 & 23.7 & 0.5451 \\
\hline WOMAC function 1 year & 21.4 & 21.4 & 22.7 & 22.5 & 0.6734 \\
\hline WOMAC total 1 year & 20.1 & 19.6 & 21.6 & 20.9 & 0.6541 \\
\hline ROM 1 year $\left({ }^{\circ}\right)$ & 110.1 & 12.2 & 109.5 & 14.7 & 0.338 \\
\hline
\end{tabular}

resection technique with standard cutting blocks and instruments. Intramedullary referencing was applied at the femur and extramedullary referencing at the tibia. In accordance with the hospital's clinical routine, the patella was left unresurfaced. All operations were performed by consultant orthopedic surgeons specialized in knee arthroplasty or under the supervision of one of these surgeons. Patient positioning, antibiotic and deep vein thrombosis prophylaxis, draping, and tourniquet control were standardized. All patients underwent the same standardized rehabilitation program after surgery. $\mathrm{Pa}$ - tients were mobilized from the first postoperative day under supervision of the physiotherapists of the university hospital. Exercises included continuous passive motion, assisted and unassisted knee extension, walking and stair climbing with two crutches and progression as tolerated. For patient-reported outcome measurement the Western Ontario and McMaster Universities osteoarthritis index (WOMAC score) [3] was available from the arthroplasty registry. The questionnaire was applied in the German language version [24] (main outcome parameter). The questionnaire was com- pleted on the day before surgery and postoperatively 1 year after surgery. The WOMAC questionnaire collected data on pain, stiffness, and physical function. Every item was completed on an 11-point scale and converted for analysis purposes to a scale from 0 to 100,0 denoting the best and 100 the worst response. The score for each of the three main dimensions was defined as the sum of all item scores divided by the number of items. The total score was defined as the sum of pain, stiffness and function scores divided by three.

The ROM data collected with goniometers during clinical routine were taken from the medical records for the following points in time: preoperative, postoperative days 4 and 10 and 1 year.

As descriptive measures for WOMAC scores and ROM at different time points we estimated mean value and standard deviation. Differences between groups were tested for preoperative and postoperative WOMAC scores applying the Mann-Whitney U-test and for ROM applying the t-test. Prosthesis survival was estimated with the Kaplan-Meier method from date of surgery until date of revision, data of death or end of follow-up (31 December 2015), whichever occurred first. We report Kaplan-Meier estimates for prosthesis survival at $1-5$ years together with $95 \%$ confidence intervals (CI). Differences in survival curves were tested using the log-rank test. Data analysis was performed with Stata Version 13 (StataCorp LP, College Station, TX, USA). 
Orthopäde 2021 · 50:674-680 https://doi.org/10.1007/s00132-021-04068-x

(c) The Author(s) 2021

R. Lechner · M. Lazzeri · W. Oberaigner · P. Nardelli · T. Roth · P. Köglberger $\cdot$ M. Krismer $\cdot$ M. C. Liebensteiner

Does the type of surgical approach affect the clinical outcome of total knee arthroplasty?

Abstract

Background. The aim of the study was to investigate the issue of medial midvastus (MMV) vs. medial parapatellar (MPP) approaches in total knee arthroplasty (TKA). It was hypothesized that the two surgical approaches would produce significantly different results with respect to patientreported knee score outcome (hypothesis 1), short-term postoperative range of motion (ROM) (hypothesis 2), long-term postoperative ROM (hypothesis 3 ) and prosthesis survival (hypothesis 4).

Methods. A retrospective comparative study design was applied. Data sets were obtained from the state arthroplasty registry. The Western Ontario and McMaster
Universities osteoarthritis index (WOMAC) data were analyzed from preoperative and 1 year postoperatively. The ROM data were analyzed for the time points preoperative, postoperative days 4 and 10 and 1 year. Results. Available were 627 cases (407 MMV vs. $220 \mathrm{MPP}$ ) and 1 year postoperatively there were no significant differences between groups regarding the WOMAC scores (hypothesis 1 ). Early postoperatively on days 4 and 10 after TKA there were no differences between groups ( $p=0.305$ and $p=0.383$, respectively, hypothesis 2 ). Likewise, ROM did not significantly differ between the groups 1 year after TKA ( $p=0.338$, hypothesis 3 ). The 5 -year prosthesis survival did not differ between the groups and showed $94.46 \%$ (95\% confidence interval, Cl 90.69-96.73\%) in the MMV group and $94.33 \%(95 \% \mathrm{Cl}$ $89.96-96.83 \%)$ in the MPP group ( $p=0.664$, hypothesis 4).

Conclusion. Both surgical approaches produce equivalent clinical results in terms of early postoperative ROM, late postoperative ROM and 1-year WOMAC. The same prosthesis survival rates can be expected.

Keywords

Prosthesis survival · Surgical procedures, operative $\cdot$ Knee surgery $\cdot$ Range of motion . Functional outcome

\section{Beeinflusst die Art des chirurgischen Zugangs das klinische Ergebnis der Knietotalendoprothese?}

\section{Zusammenfassung}

Hintergrund. Ziel der Studie war es, den medialen Midvastus- (MMV) vs. medialen parapatellaren (MPP) Zugang bei der Knietotalendoprothetik (TKA) zu untersuchen. Es wurde die Hypothese aufgestellt, dass die beiden operativen Zugänge zu signifikant unterschiedlichen Ergebnissen hinsichtlich des vom Patienten berichteten Kniescores (Hypothese 1), des kurzfristigen postoperativen Bewegungsumfangs (ROM; Hypothese 2), des langfristigen postoperativen ROM (Hypothese 3) und des Prothesenüberlebens (Hypothese 4) führen würden.

Methoden. Ein retrospektiv vergleichendes Studiendesign wurde angewandt. Die Datensätze wurden aus dem staatlichen Endoprothesenregister entnommen. Die
Daten des Western Ontario and McMaster Universities Osteoarthritis Index (WOMAC) wurden präoperativ und 1 Jahr postoperativ analysiert. Die ROM-Daten wurden für die Zeitpunkte präoperativ, postoperativ Tag 4 und 10 sowie 1 Jahr analysiert.

Ergebnisse. Es standen 627 Fälle zur Verfügung (407 MMV vs. 220 MPP), und 1 Jahr postoperativ gab es keine signifikanten Unterschiede zwischen den Gruppen hinsichtlich der WOMAC-Scores (Hypothese 1). Früh postoperativ an Tag 4 und 10 nach TKA gab es keine Unterschiede zwischen den Gruppen ( $p=0,305$ bzw. $p=0,383$; Hypothese 2). Ebenso unterschied sich das ROM 1 Jahr nach TKA nicht signifikant zwischen den Gruppen $(p=0,338$; Hypothese 3$)$. Das 5-Jahres-
Prothesenüberleben unterschied sich nicht zwischen den Gruppen und zeigte $94,46 \%$ (95\% Konfidenzintervall [KI] 90,69-96,73\%) in der MMV-Gruppe und $94,33 \%$ (95\% KI $89,96-96,83 \%)$ in der MPP-Gruppe $(p=0,664$; Hypothese 4).

Schlussfolgerung. Beide chirurgischen Ansätze führen zu gleichwertigen klinischen Ergebnissen in Bezug auf frühes postoperatives ROM, spätes postoperatives ROM und 1-Jahres-WOMAC. Es können die gleichen Prothesenüberlebensraten erwartet werden.

\section{Schlüsselwörter}

Prothesenüberleben - Operationsverfahren . Kniechirurgie - Bewegungsumfang ·

Funktioneller Outcome
Alpha was defined as 0.05 (two-tailed tests).

\section{Results}

Available for analysis were 627 cases (407 MMV vs. $220 \mathrm{MPP}$ ). In the MMV group the mean age was $70.1 \pm 9.1$ years, $64.1 \%$ of the participants were female and in $43.7 \%$ the left side was operated. In the MPP group the mean age was $69.0 \pm 9.7$ years, $57.7 \%$ of the participants were female and in $45.5 \%$ the left side was operated. None of these demographic parameters differed significantly between the groups. Preoperative leg axis (mFTA) from whole leg radiographs was also similar between the groups (- Table 1 ).

In the MMV group the WOMAC total improved from 51.6 preoperatively to 20.1 at 1 year postoperatively. In the MPP group the WOMAC total improved from 51.2 preoperatively to 21.6 at 1 year postoperatively. At 1 year postoperatively there were no significant differences between groups in either WOMAC total or in the three WOMAC subscores (hypothesis 1, • Table 1).
Preoperative $\mathrm{ROM}$ was $109.5^{\circ}$ in the MMV group and $108^{\circ}$ in the MPP group $(p=0.2819)$. Early postoperatively on days 4 and 10 after TKA there were also no differences between groups $(p=0.3049$ and $p=0.3828$, hypothesis 2 , - Table 1 ). Likewise, ROM was not significantly different between the groups 1 year after TKA ( $p=0.3376$, hypothesis 3, - Table 1).

The 5-year prosthesis survival did not differ between groups and showed $94.46 \%$ (95\% CI $90.69-96.73 \%)$ in the MMV group and $94.33 \% \quad(95 \%$ 
Table 2 Current knowledge on clinical outcome of total knee arthroplasty performed with either the medial midvastus (MMV) or the medial parapatellar (MPP) approach

\begin{tabular}{|c|c|c|c|c|c|c|}
\hline Author & Year & $n$ & Outcome parameters & FU periods & Results & Resumé \\
\hline $\begin{array}{l}\text { Aslam } \\
\text { et al. [1] }\end{array}$ & 2017 & 42 vs. 42 & $\begin{array}{l}\text { KSS, VAS, SLR, extensor lag, hospital stay, } \\
\text { LRR rate, blood loss, patellar tracking }\end{array}$ & $\begin{array}{l}\text { Day } 1,1 \text { week, } \\
1 \text { month, } 3 \text { months, } \\
6 \text { months, } 1 \text { year }\end{array}$ & $\begin{array}{l}\text { MMV: better KSS at } 1 \text { week and } 1 \text { month, } \\
\text { earlier SLR, less LRR, shorter stay }\end{array}$ & Pro MMV \\
\hline $\begin{array}{l}\text { Bäthis } \\
\text { et al. [2] }\end{array}$ & 2005 & 25 vs. 25 & VAS, Q-strength, proprioception & 3 weeks, 6 weeks & $\begin{array}{l}\text { MMV: less pain, higher Q-strength, no } \\
\text { difference in ROM }\end{array}$ & Pro MMV \\
\hline $\begin{array}{l}\text { Dalury } \\
\text { and Ji- } \\
\text { ranek [4] }\end{array}$ & 1999 & 24 vs. 24 & $\begin{array}{l}\text { Q-strength, VAS, SLR, ROM at discharge, } \\
\text { radiographic outcome }\end{array}$ & 6 weeks, 12 weeks & $\begin{array}{l}\text { MVV: higher Q-strength at } 6 \text { and } 12 \\
\text { weeks, less pain and earlier SLR }\end{array}$ & Pro MMV \\
\hline $\begin{array}{l}\text { Dalury } \\
\text { et al. [5] }\end{array}$ & 2008 & 20 vs. 20 & $\begin{array}{l}\text { Radiograph, electromyography, nerve con- } \\
\text { duction studies, ROM tests, and KSS, VAS, } \\
\text { hospital stay, blood loss, radiographic out- } \\
\text { come }\end{array}$ & 6 weeks, 12 weeks & No difference & Equal \\
\hline $\begin{array}{l}\text { Engh et al. } \\
\text { [6] }\end{array}$ & 1997 & 61 vs. 57 & $\begin{array}{l}\text { LRR rate, patellar tracking, Q-strength, ROM, } \\
\text { SLR }\end{array}$ & 6 weeks & No difference & Equal \\
\hline $\begin{array}{l}\text { Gelfer } \\
\text { et al. [10] }\end{array}$ & 2003 & $\begin{array}{l}30 \text { (both } \\
\text { groups) }\end{array}$ & $\begin{array}{l}\text { Patellar perfusion (bone scan), AKP, grind } \\
\text { test, HSS }\end{array}$ & $2,3,6$ weeks & No difference & Equal \\
\hline $\begin{array}{l}\text { Keating } \\
\text { et al. [14] }\end{array}$ & 1999 & $\begin{array}{l}100 \text { vs. } \\
100\end{array}$ & $\begin{array}{l}\text { LRR, ROM day 2, ROM at discharge, SLR, } \\
\text { extensor lag }\end{array}$ & First weeks & No difference & Equal \\
\hline $\begin{array}{l}\text { Layher } \\
\text { et al. [17] }\end{array}$ & 2016 & 9 vs. 10 & $\begin{array}{l}3 \mathrm{D} \text { gait analysis ( } 5 \text { weeks, } 6 \text { months), KSS; } \\
\text { WOMAC, SLR, STS, VAS, ROM at discharge, } \\
\text { radiographic outcome }\end{array}$ & 5 weeks, 6 months & $\begin{array}{l}\text { MMV: worse ROM at discharge, better } \\
\text { sagittal knee moment ( } 5 \text { weeks) and } \\
\text { knee power ( } 5 \text { weeks, } 6 \text { months), better } \\
\text { WOMAC } 6 \text { months }\end{array}$ & Equal \\
\hline $\begin{array}{l}\text { Maestro } \\
\text { et al. [19] }\end{array}$ & 2000 & 25 vs. 17 & $\begin{array}{l}\text { KSS, ROM, LRR rate, ROM, active knee exten- } \\
\text { sion }\end{array}$ & $1,6,12$ months & $\begin{array}{l}\text { MMV: less LRR, better active knee ex- } \\
\text { tension day } 5 \text {, better ROM at discharge }\end{array}$ & Pro MMV \\
\hline $\begin{array}{l}\text { Nutton } \\
\text { et al. [20] }\end{array}$ & 2014 & 12 vs. 16 & $\begin{array}{l}\text { Walking, stairs, SLR, stay, inpatient mobil- } \\
\text { ity milestones, knee kinematics, muscle } \\
\text { strength, timed up and go, WOMAC, and } \\
\text { daily step count, Q-strength, SLR }\end{array}$ & $\begin{array}{l}6 \text { weeks, } 3 \text { months, } \\
6 \text { months }\end{array}$ & $\begin{array}{l}\text { No difference: time to walking, stairs, } \\
\text { SLR, discharge, timed up and go, } \\
\text { WOMAC, ROM, extensor strength }\end{array}$ & Equal \\
\hline $\begin{array}{l}\text { Shukla } \\
\text { et al. [23] }\end{array}$ & 2017 & 24 vs. 28 & KSS; duration of hospital stay, blood loss & $\begin{array}{l}2 \text { weeks, } 6 \text { weeks, } 3 \\
\text { months, } 6 \text { months, } \\
1 \text { year }\end{array}$ & $\begin{array}{l}\text { MVV: better KSS } 2 \text { weeks, } 6 \text { weeks, } 3 \\
\text { months }\end{array}$ & Pro MMV \\
\hline $\begin{array}{l}\text { White } \\
\text { et al. [25] }\end{array}$ & 1999 & $\begin{array}{l}109 \text { vs. } \\
109\end{array}$ & $\begin{array}{l}\text { Surgical time, LRR rate, and total blood loss. } \\
\text { pain, ROM, SLR }\end{array}$ & $\begin{array}{l}\text { Day } 8,6 \text { weeks, } 6 \\
\text { months }\end{array}$ & $\begin{array}{l}\text { MVV: less LRR, less pain at day } 8 \text { and } 6 \\
\text { weeks, better SLR at day } 8\end{array}$ & Pro MMV \\
\hline
\end{tabular}

CI $89.96-96.83 \%)$ in the MPP group $(p=0.6639$, hypothesis 4 , • Fig. 2).

\section{Discussion}

It is regarded as the most important finding that the surgical approaches MMV and MPP did not significantly differ with respect to patient-reported knee score outcome (WOMAC), short-term postoperative ROM (day 4 and day 10), longterm postoperative ROM (1 year) or prosthesis survival.

For the purpose of comparing these findings with those of previous researchers a comprehensive literature analysis was performed. The search term "total AND knee AND (arthroplasty OR replacement) AND midvastus" produced 94 matches. After excluding irrelevant studies and those comparing approaches other than MMV and MPP there remained 15 original research articles $[1,2,4-7,10,14,16$, 17, 19-21, 23, 25]. While three investigated solely surrogate parameters [7, 16, 21] (e.g. intraoperative tension in the lateral retinaculum), the remaining 12 studies (- Table 2 ) provided clinical outcome, at least in part: knee scores, such as WOMAC and KSS, early and late postoperative ROM, VAS for pain, SLR ability, other rehabilitation milestones etc. (- Table 2). At first glance it seems highly incongruent because six of those studies favored the MMV approach [1, $2,4,19,23,25]$ while the other six studies reported no such advantages of the MMV approach $[5,6,10,14,17$, 20]; however, when only considering very early postoperative follow-up intervals there seems to be some agreement amongst the authors that the MMV approach led to slightly better findings [1, $2,19,23,25]$. In detail, those studies tested parameters, such as quadriceps strength, time that SLR was possible and pain. In a synopsis of the previous literature and also taking into account the findings of the current study, MMV seems to have some advantages regarding 
rehabilitation in the early postoperative weeks, differences which disappear over time with most of them already after 2 months.

Regarding sample size most of the previous studies recruited around 50 patients for both groups together. Only 2 of the previous studies reported much higher sample sizes of around 200 for both groups together [14, 25]. The findings of the study at hand are highlighted by the fact that it is by far the largest study conducted so far with an overall sample size of more than 600 . The current study is also the first investigation to link the issue of surgical approaches to prosthesis survival. The fact that both surgical approaches resulted in similar prosthesis survival suggests that the MMV approach obviously did not exert negative influences on TKA longevity.

The following limitations of the study are acknowledged. The outcome parameters were predominantly mid-term (1year WOMAC, 1-year ROM, 1-5-year survival). Only few parameters dealt with early postoperative function (day $4 \mathrm{ROM}$ and day $10 \mathrm{ROM}$ ). This must be regarded as a limitation because potential early postoperative benefits of the MMV approach might therefore have been overlooked. Parameters, such as SLR, stair climbing, Q-strength would have been of additionalvalue. Also, it would have been beneficial to include knee score data, such as the WOMAC from 3 months postoperative. Other limitations are the facts that the patients were operated on by a large variety of surgeons and that no outcome parameters other than those mentioned above could be collected due to the retrospective nature of the study. The following facts are regarded as strengths of the study. It was the largest study conducted to date with an overall sample size of more than 600. Data quality is regarded as very robust as data originate from the state arthroplasty registry. Another advantage was that for the first time the question of the surgical approach in TKA was linked to prosthesis survival as reported from an arthroplasty registry.

The clinical relevance of the findings is regarded as high. Both surgical approaches may be used in daily practice during TKA. Using the MMV approach does not negatively affect prosthesis survival in the long run.

\section{Conclusion}

On the basis of the findings, it is concluded that both surgical approaches in primary TKA, MMV and MPP, produce equivalent clinical results in terms of early postoperative ROM, late postoperative ROM and knee score outcome. The same prosthesis survival rates can be expected when using the MMV or the MPP approach in primary TKA. Consequently, the question whether to perform MMV or MPP depends on the surgeon's preference.

\section{Corresponding address}

\section{Paul Köglberger}

Division of Intensive Care and Emergency

Medicine, Department of Internal Medicine,

Medical University Innsbruck

Innsbruck, Austria

paul.koeglberger@i-med.ac.at

Acknowledgements. Professional language editing of the manuscript by Mary H. Margreiter is acknowledged.

Funding. This research did not receive any specific grant from funding agencies in the public, commercial, or not-for-profit sectors.

Funding. Open access funding provided by University of Innsbruck and Medical University of Innsbruck.

\section{Compliance with ethical guidelines}

Conflict of interest. R. Lechner, M. Lazzeri, W. Oberaigner, P. Nardelli, T. Roth, P. Köglberger, M. Krismer and M.C. Liebensteiner declare that they have no competing interests.

Ethical standards. For this article no studies with human participants or animals were performed by any of the authors. All studies performed were in accordance with the ethical standards indicated in each case. IRB: Medical University Innsbruck (approval No. AN2016-0208, 367/4.3)

Open Access. This article is licensed under a Creative Commons Attribution 4.0 International License, which permits use, sharing, adaptation, distribution and reproduction in any medium or format, as long as you give appropriate credit to the original author(s) and the source, provide a link to the Creative Commons licence, and indicate if changes were made. The images or other third party material in this article are included in the article's Creative Commons licence, unless indicated otherwise in a credit line to the material. If material is not included in the article's Creative Com- mons licence and your intended use is not permitted by statutory regulation or exceeds the permitted use, you will need to obtain permission directly from the copyright holder. To view a copy of this licence, visit http://creativecommons.org/licenses/by/4.0/.

\section{References}

1. Aslam MA, Sabir AB, Tiwari V et al (2017) Approach to total knee replacement: a randomized double blind study between medial parapatellar and midvastus approach in the early postoperative period in asian population. JKnee Surg 30:793-797

2. Bathis H, Perlick L, Blum C et al (2005) Midvastus approach in total knee arthroplasty: a randomized, double-blinded study on early rehabilitation. Knee Surg Sports Traumatol Arthrosc 13:545-550

3. Bellamy N, Buchanan WW, Goldsmith $\mathrm{CH}$ et al (1988) Validation study of WOMAC: a health status instrument for measuring clinically important patient relevant outcomes to antirheumatic drug therapy in patients with osteoarthritis of the hip or knee. JRheumatol 15:1833-1840

4. Dalury DF, Jiranek WA (1999) A comparison of the midvastus and paramedian approaches for total knee arthroplasty. J Arthroplasty 14:33-37

5. Dalury DF, Snow RG, Adams MJ (2008) Electromyographic evaluation of the midvastus approach. JArthroplasty 23:136-140

6. Engh GA, Holt BT, Parks NL (1997) A midvastus muscle-splitting approach for total knee arthroplasty. J Arthroplasty 12:322-331

7. Engh GA, Parks NL, Ammeen DJ (1996) Influence of surgical approach on lateral retinacular releases in total knee arthroplasty. Clin Orthop Relat Res. https://doi.org/10.1097/00003086-19961000000008

8. Gaillard R, Cerciello S, Lustig S et al (2017) Risk factors for tibial implant malpositioning in total knee arthrosplasty-consecutive series of one thousand, four hundred and seventeen cases. Int Orthop 41:749-756

9. Gandhi R, Davey JR, Mahomed NN (2008) Predicting patient dissatisfaction following joint replacement surgery. JRheumatol 35:2415-2418

10. Gelfer Y, Pinkas L, Horne Tet al (2003) Symptomatic transient patellar ischemia following total knee replacement as detected by scintigraphy. A prospective, randomized, double-blind study comparing the mid-vastus to the medial parapatellarapproach. Knee 10:341-345

11. GunstS, VillaV, Magnussen Retal (2016) Equivalent results of medial and lateral parapatellar approach for total knee arthroplasty in mild valgus deformities. Int Orthop 40:945-951

12. Hirschmann MT, Becker R (2015) The unhappy total knee replacement. Springer, Heidelberg

13. Huang AB, Wang HJ, Yu JK et al (2016) Optimal patellar alignment with minimally invasive approaches in total knee arthroplasty after a minimum five year follow-up. Int Orthop 40:487-492

14. Keating EM, Faris PM, Meding JB et al (1999) Comparison of the midvastus muscle-splitting approach with the median parapatellar approach in total knee arthroplasty. J Arthroplasty 14:29-32

15. Keurentjes JC, Fiocco M, So-Osman C et al (2013) Patients with severe radiographic osteoarthritis have a better prognosis in physical functioning after hip and knee replacement: a cohort-study. Plos One 8:e59500

16. Komatsu T, Ishibashi $Y$, Otsuka $\mathrm{H}$ et al (2003) The effect of surgical approaches and tourniquet 
application on patellofemoral tracking in total knee arthroplasty. J Arthroplasty 18:308-312

17. Layher F, Zipfel M, Sander Ket al (2016) Functional comparison of the outcome after midvastus and medial parapatellar surgical approach in total knee arthroplasty. ZOrthop Unfall 154:50-57

18. Li Z, Cheng W, Sun L et al (2018) Mini-subvastus versus medial parapatellar approach for total knee arthroplasty: a prospective randomized controlled study. Int Orthop 42:543-549

19. Maestro A, Suarez MA, Rodriguez L et al (2000) The midvastus surgical approach in total knee arthroplasty. International Orthopaedics (SICOT) 24:104-107

20. Nutton RW, Wade FA, Coutts FJ et al (2014) Short term recovery of function following total knee arthroplasty: a randomised study of the medial parapatellar and midvastus approaches. Arthritis 2014:173857

21. Ozkoc G, Hersekli MA, Akpinar S et al (2005) Time dependent changes in patellar tracking with medial parapatellar and midvastus approaches. Knee Surg Sports Traumatol Arthrosc 13:654-657

22. Rossi R, Cottino U, Bruzzone M et al (2018) Total knee arthroplasty in the varus knee: tips and tricks. Int Orthop. https://doi.org/10.1007/s00264-0184116-3

23. Shukla R, Mahajan P, Singh Met al (2017) Outcome of total knee replacement via two approaches in Indian scenario. JKnee Surg 30:174-178

24. Stucki G, Meier D, Stucki S et al (1996) Evaluation of a German version of WOMAC (Western Ontario and McMaster Universities) Arthrosis Index. ZRheumatol 55:40-49

25. White RE Jr., Allman JK, Trauger JA et al (1999) Clinical comparison of the midvastus and medial parapatellar surgical approaches. Clin Orthop Relat Res 1999(367):117-122

Hans-Henning Epperlein, Klaus Wichmann, Andreas Deussen

\section{Funktionelles Fitnesstraining}

\section{0 Übungen für Breiten-, Leistungssportler und Übungsleiter}

\section{Springer 2021, 2. Auflage, 419 S., 930 Abb., 49,99 (Softcover 39,99) EUR}

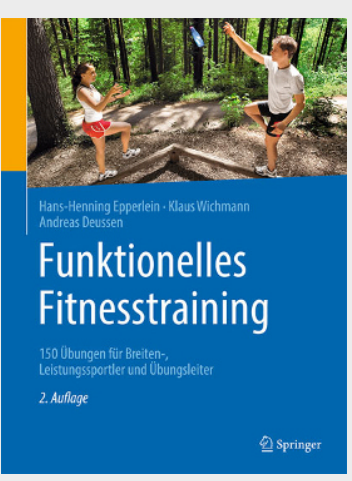

Das ,Projekt der aktiven Lebensführung', dem das außerordentliche Engagement der Autoren gilt, ist gerade heute durch die zunehmende Technisierung und Digitalisierung der Umwelt von besonderer Bedeutung. Die Autoren beginnen mit einer geschichtlichen Reflexion zum Thema Bewegung und Gymnastik bei ,den alten Griechen', was zunächst befremdlich wirkt, doch durch die konsequente Fortsetzung und die differenzierte Darstellung der geschichtlichen Entwicklung des Begriffs,Gymnastik' bis in die heutige Zeit werden interessante Chancen aufgezeigt, wie das funktionelle Fitnesstraining heute in den Kontext des Wirkungsverständnisses eines selbstbestimmten Lebens eingebracht werden kann. Nachdem eine prägnante und fokussierte Darstellung der anatomischen und physiologischen Grundlagen für das Verständnis der Hintergründe des funktionellen Fitnesstrainings erfolgt ist, werden diagnostische Verfahren zur Erfassung der körperlichen Fitness (Kraft, Beweglichkeit, Ausdauer) erläutert. Hierbei wird der Hintergrund des jeweiligen Testansatzes durch ansprechende Bilder und entsprechende Dokumentationsbögen verständlich, plausibel und nachvollziehbar dargestellt. Sollten bei der Durchführung der Übungen Defizite erkannt werden, verweisen die Autoren direkt auf mögliche Übungen im nachfolgenden Text. Dadurch ist es möglich, zwischendurch auch einmal zielgerichtet ,querzulesen', um dann aber wieder an der Stelle weiterzulesen, bei der man aufgehört hatte.

Den Hauptteil des Buches bilden die Darlegungen zu verschiedenen Übungen des funktionellen Fitnesstrainings. Im Unterschied zu sonstigen Ansätzen werden hierbei verschiedene Trainingsorte in den Fokus genommen, neben dem klassischen Hallentraining auch Übungen im Wald oder am Strand. Dieser Wechsel der Umgebungsperspektive gibt sehr viele motivierende Impulse für ein abwechslungsreiches Gestalten der Übungen, was für das Aufrechterhalten der Motivation der Teilnehmer*innen einen wichtigen Punkt darstellt. Die Darstellung der Übungen ist klar gegliedert und differenziert nach Schwierigkeitsgrad, Ort und beanspruchter Muskulatur. Der Fließtext des Buches wird durch alltagstaugliche ,Praxistipps' aufgelockert, die nicht nur für Einsteiger*innen in den Bereich des funktionellen Fitnesstrainings hilfreich sind. Wie bereits erwähnt, begleiten und ergänzen die Bilder den Text hervorragend und vor allem ist in den Fotos auch der Spaß und die Freude der Personen an den Übungen festgehalten worden.

Durch die evidenzbasierte Vorgehensweise im Aufbau der Übungen und der Trainingsgestaltung leisten die Autoren mit ihrem Buch einen wichtigen Transfer von interdisziplinären sport-, bewegungs- und gesundheitswissenschaftlichen Ansätzen in den Breiten- und Leistungssport. Die Betrachtung und der Vermittlungsansatz sind in sich konsistent und zeichnen sich durch einen hohen Praxisbezug und die durch viele Bilder sehr anschauliche Darstellungsweise aus. Das Besondere an dem vorliegenden Buch ist die stete Verknüpfung und Bezugnahme von Inhalten der verschiedenen Kapitel. Die Gliederung und die Verweise auf vorherige oder folgende Buchkapitel sind so eingebunden, dass man beim Lesen nicht den Faden verliert, sondern immer gezielt bei verschiedenen Fragestellungen (z.B. Verlust der Kraft in der Bauchmuskulatur) durch das Buch geleitet wird. So ist es ohne viele Umstände möglich, hier innerhalb von kurzer Zeit ein entsprechendes Trainingsprogramm aufzustellen. Das Buch wird erfolgreich dazu beitragen, das ,Projekt der aktiven Lebensweise' mit Spaß und Freude an der Bewegung umzusetzen.

Prof. (apl.) Dr. rer. nat. Klara Brixius, Universität der Bundeswehr München 
Hier steht eine Anzeige.

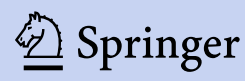

